\title{
A WAY TO SAVE THE NATION'S WITH DRUG-FREE
}

\author{
Yanto RAMLI ${ }^{1}$, Mochamad SOELTON², Harefan ARIEF ${ }^{3}$, Eko Tama Putra SARATIAN ${ }^{4}$, \\ Tati NUGRAHATI ${ }^{5}$, Imron ROSADI ${ }^{6}$, Dewi ANGGRAINI ${ }^{7}$, and Tri WAHYONO ${ }^{8}$ \\ 1,2,3,4,5,8 Universitas Mercu Buana, Indonesia \\ ${ }^{6}$ Ministry of Social Affairs, Republik Indonesia \\ ${ }^{7}$ Dian Nusantara University; * soelton@mercubuana.ac.id
}

\begin{abstract}
This is a community service related to the treatment and educational assistance on prevention of drug abuse for parents and families around children. West Jakarta, with a very full population density in DKI Jakarta, has a potential problem with its environment. We try to map sustainable efforts to prevent drug abuse, focusing on providing education from an early age to children aged under five is one way to shape children's character and personality for the future. In the GEPENTA Program (2002), Indonesian Health Officials stated that the daily growth rate was $0.065 \%$ of the total population of 200 million people, or the same as 130,000 people per day. The 2018 World Drugs Reports published by the United Nations Office on Drugs and Crime (UNODC), said that as many as 275 million people in the world or 5.6\% of the world's population (aged 15-64 years) have used drugs. Meanwhile in Indonesia, the National Narcotics Agency (BNN) as the focal point in the field of Prevention and Eradication of Drug Abuse and Illicit Drug Trafficking (P4GN) has the number of drug abuse in 2017 as many as 3,376,115 people between the ages of 10-59 years. Meanwhile, the number of drug abuse among students in 2018 (from 13 provincial capitals in Indonesia) reached 2.29 million people. Soelton and Nugrahati's research, 2018, concluded that one of the groups of people who are prone to being exposed to drug abuse are those in the 15-35 age range or the millennial generation.
\end{abstract}

Keywords: Drugs, Millennials, Young Generation, National Improvement

\section{BACKGROUND}

According to Soelton et, al, (2018), the social, economic, and cultural changes that occur in the society today are running so fast that they cause complexity in various spectrums. One of the influential changes is the process of changing the culture of society from the traditional things to the modern ones, or it is often called or referred to as the modernization. The modernization and the era of globalization are reaching out to all elements of society, including the younger generation. The process of globalization arises as a result of the flow of information and communication that is easily accessible even at relatively cheap costs. As a result, the people are unprepared in facing the cultural changes that occur in their environment and they caused social problems.

The changes in cultural elements are often responded to by various people. For the people who are not ready to accept the changes that occur, there will be a shock in social and cultural life that results in the individuals being left behind or frustrated. Such conditions can cause a situation that is not balanced and not harmonious in their life. This is called Cultural Shock or Cultural Concussion. For example: in this era of globalization, the elements of foreign culture such as the pattern of hedonic promiscuity (worshiping luxury), the consumptive lifestyles have become a pattern of association, and the lifestyle of our teenagers. Until now the spread of drugs is almost inevitable. Almost all of the world's population can easily get drugs through communication and information tools that are very accessible. Of course, this makes parents, teachers / educators, government, and all elements of the nation feel worried about the spread of the uncontrolled drugs (Soelton et, al, 2018).

There is more and more abuse of illegal drugs or what is better known as drugs. Drug abuse is increasing day by day. In the GEPENTA Program (2002), Indonesian Health
Officials stated that the daily growth rate was $0.065 \%$ of the total population of 200 million people or the same as 130,000 people per day. The 2018 World Drugs Reports published by the United Nations Office on Drugs and Crime (UNODC), said that as many as 275 million people in the world or 5.6\% of the world's population (aged 15-64 years) have used drugs. Meanwhile in Indonesia, the National Narcotics Agency (BNN) as the focal point in the field of Prevention and Eradication of Drug Abuse and Illicit Drug Trafficking (P4GN) has the number of drug abuse in 2017 as many as 3,376,115 people between the ages of 10-59 years. Meanwhile, the number of drug abuse among students in 2018 (from 13 provincial capitals in Indonesia) reached 2.29 million people. One of the groups of people who are prone to being exposed to drug abuse are those in the age range 15-35 years or the millennial generation (Soelton et al., 2018; Soelton and Nugrahati, 2018).

West Jakarta with an area of $127.11 \mathrm{~km} 2$ has 8 subdistricts, 56 wards, consisting of 2,260341 people. Geographically, the northern part of West Jakarta is bordered by the Administrative City of North Jakarta, the western part is bordered by Banten Province (Tangerang City and South Tangerang), and the eastern part is bordered by the Administrative City of West Jakarta, South Jakarta (for the South region). The highest population was in the age range of 25-29 years with 944.3 thousand people, 3539 years with 931.7 thousand people, and 30-34 years with 926.2 thousand people. Meanwhile, the lowest population was in the age range of 75 years and over as many as 120.3 thousand people, $70-74$ years with 155.3 thousand people, and 65-59 years with 250.7 thousand people. This projection is contained in the 2015 Supas results entitled 2015-2045 Indonesian Population Projection.

The density level in the data description above illustrates how dense and full the West Jakarta area is, 
especially for children aged 19 years and under. Referring to Bruner's statement, children's introduction to the character of their nation needs to be packaged through games combined with character education themes. The integrated learning system application makes learning not requiring additional lesson hours. Therefore, it is necessary to think about the technique of packaging learning materials through various interesting games so that they are easily absorbed by children.

According to Soelton et al., 2018: Individuals who are involved in drug abuse until they end up experiencing dependence will have a bad impact not only on themselves but also on the surrounding environment. For example, damaged kinship, reduced learning ability, the inability to distinguish between good and bad, and mental and behavioral changes to be antisocial. Even in the Daily Republika, Sunday, February 13, 2005 Prof. Dr. Zubairi Djoeban, FKUI hematologist said that around $30 \%$ of narcotics users will be infected with HIV / AIDS. This concern is not unfounded, because many of its users are teenagers. According to Hawari (2002) in his research, it is stated that $97 \%$ of drug abusers are adolescents. As stated by Hawari (2002) in his research, it is stated that the influence / persuasion of friends is $81.3 \%$ from the beginning a person uses drugs.

Teens who find it difficult to be different from their peers usually have very high group solidarity. Adolescents who cannot survive in the midst of differences with their environment tend to encounter obstacles in presenting themselves, expressing their rights, expressing their thoughts, feelings, and beliefs. Finally, these adolescents allow themselves to be immersed in the same environmental identities of their peers, such as what happens to adolescents who abuse drugs. To avoid this, it is necessary in adolescents to have an ability that supports their process of socializing. The ability to remain yourself in the socializing is also needed so as not to fall into the development of harmful behaviors. Ability to express oneself honestly and accordingly in upholding personal rights and expressing thoughts, feelings, feelings and beliefs without compromising the rights of others or harming others around them. In other words, teenagers really need the ability to be assertive. Assertive is also a social skill that allows a person to relate effectively to others (Alberti and Emmons, 1995). Assertiveness is not a characteristic that suddenly appears in adolescence, nor is it a factor brought on by an individual since he was born.

The basic understanding of the meaning of drugs and their types and their impact on the younger generation as the hope of the nation and the state is very important and urgent. Narcotics is an abbreviation of the narcotics, the psychotropic substances, and the addictive substances. Drugs are medicine, the ingredients, the substances that are drunk / smoked / swallowed, or injected and it can cause dependence and affect the work of the brain, as well as the vital functions of other organs (the heart, the blood circulation, the breathing, etc.) Narcotics are substances or drugs derived from plants or non-plants, both synthetic and semisynthetic which cause a decrease or change in consciousness and eliminate or reduce the pain and they can cause dependence (Law No.27 / 1997) Meanwhile, according to $\mathrm{WHO}$ what is meant by the definition of this drug definition is a substance which, if inserted into the body, will affect physical and / or psychological function (except food, water, or oxygen).

The danger of drugs for the addicts (young generation) is very much and if it is not immediately stopped the habit of consuming drugs, this will worsen the health status of the users themselves slowly but surely, and certainly it can endanger the survival of this nation in the future. Youth as a generation that is expected to be the nation's successor, the more fragile the day is undermined by the addictive substances of neurological destruction, so that the young man cannot think clearly. As a result, the generation of hope for a strong and intelligent nation will only remain a memory. The target age of drug users is the student age, which ranges from 11 to 24 years. This indicates that the dangers of drugs can target our students at any time. The effects of drug use can be in various forms, including the following: 1) Causing a decrease or even change in consciousness, 2) Eliminating the senses, 3) Reducing to relieve pain, 4) Adding dependency / addiction. The greatest danger of drugs for health is the effect of the drug dependence itself. Because with the bad effects caused to drug addicts is the desire to always use it repeatedly.

Based on the situation analysis described above, the partner group's problems are stated as follows:

\section{Table 1. Problem of the Community}

\begin{tabular}{lll}
\hline No. & \multicolumn{1}{c}{ Problems } & \multicolumn{1}{c}{ Description } \\
\hline $\begin{array}{l}\text { 1. } \\
\text { The lack of parental understanding of the } \\
\text { importance of affective activities for teenagers about } \\
\text { the dangers and effects caused by drugs abuse. }\end{array}$ & $\begin{array}{l}\text { The lack of the role and participation of parents and teachers to teach teenagers concerning } \\
\text { affective education in South Meruya related to drug abuse until eventually experiencing } \\
\text { dependence will have a bad impact not only on himself but also for the surrounded environment. }\end{array}$ \\
$\begin{array}{lll}\text { 2. } \\
\text { The lack of parental understanding of the } \\
\text { importance of cognitive activities for teenagers } \\
\text { about the dangers and effects of drug abuse. }\end{array}$ & $\begin{array}{l}\text { The lack of the role and participation of parents and teachers to teach teenagers concerning } \\
\text { cognitive education in South Meruya related to drug abuse until eventually experiencing } \\
\text { dependence will have a bad impact not only on himself but also for the surrounded } \\
\text { environment. }\end{array}$ \\
$\begin{array}{ll}\text { The lack of parental understanding of the } \\
\text { importance of psychomotor activities for teenagers } \\
\text { about the dangers and effects of drug abuse. }\end{array}$ & $\begin{array}{l}\text { The lack of the role and participation of parents and teachers to teach teenagers concerning } \\
\text { psychomotor activities education in South Meruya related to drug abuse until eventually } \\
\text { experiencing dependence will have a bad impact not only on himself but also for the } \\
\text { surrounded environment. }\end{array}$ \\
\end{tabular}


The purpose of this activity is as follows:

a. To increase the role and participation of parents regarding the dangers and effects of the affective focus of teenagers in drug abuse in South Meruya.

b. To increase the role and participation of parents regarding the dangers and effects of the cognitive focus of teenagers in drug abuse in South Meruya.

c. To increase the role and participation of parents regarding the dangers and effects of the psychomotor focus of teenagers in drug abuse in South Meruya. follows:

The benefits and expectation of this activity is as

a. To increase the role and participation of parents in educating their children to behave in the environment and their attitude.

b. The role and participation of the members of the family and the environment to increase the skills and expertise in the educating the children.

c. The role of the family in anticipating drug abuse that will have a bad impact not only on themselves but also on the surrounding environment

\section{METHOD}

Drug abuse prevention assistance activities that were held online through zoom on February 25, 2021 with 92 participants. This shows the high interest of the participants in gaining knowledge about drug abuse prevention. From the discussions conducted with the participants, it was revealed that so far they were actually quite familiar with the word ,drugs“. But they have not arrived at how to prevent it properly. Outreach and counseling activities will be held in Meruya Selatan, Kembangan District, West Jakarta. The target audience for this traning and socialization activity are the parents and family of the young children, Team Leader of the Family Welfare Empowerment/Pemberdayaan Kesejahteraan Keluarga (PKK) and Posyandu cadre cadres.

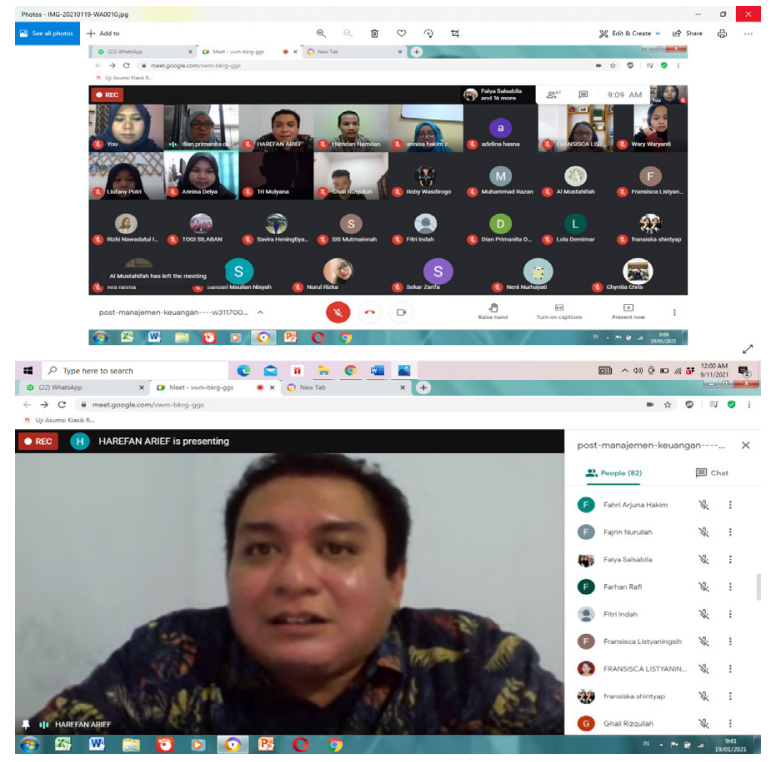

Picture 1. Program Implementation
To provide solutions to problems, the activity stages are structured as follows:

Table 2. Activities and Outcome

\begin{tabular}{|c|c|c|}
\hline No. & Activities & Outcome \\
\hline 1. & $\begin{array}{l}\text { Development of } \\
\text { extension work and } \\
\text { training programs. }\end{array}$ & $\begin{array}{l}\text { The availability of extension } \\
\text { programs and work training } \\
\text { programs so that the activities } \\
\text { carried out are more organized } \\
\text { and focused. This program } \\
\text { includes all matters of a technical, } \\
\text { managerial and time schedule. }\end{array}$ \\
\hline 2. & $\begin{array}{l}\text { Development of } \\
\text { training modules. }\end{array}$ & $\begin{array}{l}\text { Availability of modules that } \\
\text { include: Mentoring techniques, } \\
\text { continuous handling and } \\
\text { extension. }\end{array}$ \\
\hline 3. & $\begin{array}{l}\text { Persiapan sarana dan } \\
\text { prasarana pelatihan. }\end{array}$ & $\begin{array}{l}\text { Preparation of training facilities } \\
\text { and infrastructure. }\end{array}$ \\
\hline 4. & Field coordination. & $\begin{array}{l}\text { Ensure that the audience present } \\
\text { matches the target to be achieved. }\end{array}$ \\
\hline 5. & Program socialization. & $\begin{array}{l}\text { There is an understanding and } \\
\text { a common perception of the } \\
\text { purpose of this activity. }\end{array}$ \\
\hline 6. & $\begin{array}{l}\text { Assistance and } \\
\text { implementation. }\end{array}$ & $\begin{array}{l}\text { Able to find, analyze and provide } \\
\text { solutions to problems that may } \\
\text { arise from implementing the } \\
\text { program. }\end{array}$ \\
\hline 7. & $\begin{array}{l}\text { Reporting and } \\
\text { Publication }\end{array}$ & $\begin{array}{l}\text { - Activity Report } \\
\text { - Activity Report } \\
\text { - Activity Videos }\end{array}$ \\
\hline 8. & $\begin{array}{l}\text { Monitoring program } \\
\text { implementation. }\end{array}$ & $\begin{array}{l}\text { Maintain consistency in the } \\
\text { implementation of the education } \\
\text { system. }\end{array}$ \\
\hline
\end{tabular}

\section{RESULT AND DISCUSSION}

The choice of workshop or training as the main activity in PPM is because it can produce benefits: (a) Learning Facilities, participants who take part in drug abuse prevention assistance seek various information on how to prevent drug abuse, (b) Inspirational Tools, participants who take part in the training This is in getting inspiration from the materials presented and even these materials can then be applied in the environment.

The purpose of this activity is to provide socialization and counseling to improve the drugs awareness in South Meruya, West Jakarta. The objectives of this activity include: (a) increasing the role and participation of parents regarding the dangers and effects of NAFZA, the affective focus of early childhood in South Meruya, (b) increasing the role and participation of parents regarding the dangers and effects of NAFZA, the cognitive focus of children aged Early childhood in South Meruya, (c) increasing the role and participation of parents regarding the dangers and effects of NAFZA's early childhood psychomotor focus in South Meruya.

\section{CONCLUSION}

Based on the discussion from the previous chapter, in this PPM training activity, the following conclusions can be drawn: (a) the participants 'knowledge in this case is that the participants' knowledge about drug abuse is categorized as lacking, (b) it can be concluded that there 
has also been an increase in the knowledge and skills of the participants.

The suggestions that can be given after going through the results of the evaluation are as follows: (a) continuous PPM training activities are needed so that assistance can run more optimally, (b) materials should be provided directly together by conducting simulations or examples using data- the data they have so that participants can better understand the material presented, (c) mentoring activities are needed for participants who can take advantage of the routine schedule of community activities.

\section{REFERENCES}

Germas. (2016). Profil Kesehatan Kabupaten Tangerang. Dinas Kesehatan Kabupaten Tangerang

H. Robandi Roni Mohamad Arifin. Mewujudkan Anak Usia Dini yang Cerdas dalam Rangka Memasuki Pendidikan Dasar Sembilan Tahun

M Soelton, T Nugrahati, Y Ramli, D Permana, D Kurniawan. 2018. TOWARD THE BEST STRATEGY IN MINIMIZING THE SPREAD OF DRUG USERS. Proceedings International Conference and Community Development 2018. 1 (1), 171-176

Mochamad Soelton, Mohammed Hokroh, Eko Tama Putra Saratian, Tati Nugrahati, Aulia Putra, Tine Yuliantini, Febry Nur Fauzy, Miftahuddin M. Sidik. 2020. Exploring Factors That Influence Work Engagement in Social Welfare Institution at Gayo Lues Atjeh - Indonesia. American International Journal of Business Management (AIJBM) ISSN2379-106X, www.aijbm.com Volume 3, Issue 10 (October 2020), PP 46-58
R. Siti Maryam. (2008). Mengenal Usia Lanjut dan Perawatannya

Siti Nur Kholifah. (2017). Modul Ajar Cetak Keperawatan. Pusdik SDM Kesehatan

Soelton, M., Arief, H., Ramli, Y., Setiawan, M., Rohman, F., \& Mugiono, M. (2019, November). THE BEST STRATEGY FOR FORMING CHILDCARE FROM AN EARLY AGE. In ICCD (Vol. 2, No. 1, pp. 277-280).

Soelton, M., Nugrahati,T., \& Ritonga, R.(2019, November). WHAT IF OUR BELOVED CHILDREN ARE ADDOCTED TO PHONESEX?. In ICCD (Vol. 2, No. 1, pp. 273-276).

Soelton, Mochamad, Nugrahati, Tati, 2018. How Complaining Behaviors Effect on Coping Stress and Anxiety?. International Journal of Saudi Journal of Business and Management Studies (SJBMS). Vol. 3, No. 6. 623-628.

www.kemenkes.go.id unduh 10 Oktober 2020

www.kemensos.go.id unduh 17 Oktober 2020

www.data.jakarta.go.id unduh 10 Oktober 2020

http://repository.unitomo.ac.id/1112/1/Laporan $\% 20$ Pengabdian\%20Papa\%20Bambang\%20-\%20 JADI.pdf

http://staffnew.uny.ac.id/upload/131808334/pengabdian/ laporan-ppm-fix.pdf

https://id.wikipedia.org/wiki/Pendidikan_anak_usia_dini 